\title{
PENGGUNAAN METODE CURAH PENDAPAT DALAM PEMBELAJARAN MENULIS PUISI DI KELAS X IPA 2 SMA NEGERI 1 SAWAN
}

\author{
Ni Putu Kusma Dewi ${ }^{1}$, I Wayan Wendra ${ }^{2}$, Ida Bagus Putrayasa ${ }^{3}$ \\ Program Studi Pendidikan Bahasa Indonesia, Fakultas Bahasa dan Seni, Universitas \\ Pendidikan Ganesha \\ Singaraja \\ e-mail: \{kusmadewi0@gmail.com¹,wayan_wendra@yahoo.com², ibputra@gmail.com $\left.{ }^{3}\right\}$ \\ @undiksha.ac.id
}

\begin{abstract}
ABSTRAK
Penelitian ini bertujuan mendeskripsikan (1) penerapan metode Curah Pendapat oleh guru bahasa Indonesia pada pembelajaran menulis puisi (2)kendala yang dihadapi guru bahasa Indonesia dalam menerapkan metode Curah Pendapat pada pembelajaran menulis puisi (3) kendala yang dihadapi siswa ketika guru bahasa Indonesia menerapkan metode Curah Pendapat dalam pembelajaran menulis puisi (4) respons siswa terhadap pembelajaran menulis puisi menggunakan metode Curah Pendapat oleh guru bahasa Indonesia. Subjek dalam penelitian ini adalah guru bahasa Indonesia dan siswa kelas X IPA 2 di SMA Negeri 1 Sawan. Objek dalam penelitian ini adalahpenerapan metode Curah Pendapat, kendala yang dihadapi oleh guru dan siswadalam penerapan metode Curah Pendapat, serta respons dari siswa terhadap penerapan metode Curah Pendapat. Data dalam penelitian ini dikumpulkan melalui metode observasi dan wawancara. Penelitian ini menggunakan metode analisis data deskriptif kualitatif. Hasil penelitian ini menunjukkan bahwa (1) metode Curah Pendapat mampu diterapkan oleh guru dengan baik dan sesuai prosedur (2) tidak terdapat kendala yang dihadapi guru bahasa indonesia dalam menerapkan metode Curah Pendapat pada materi menulis puisi (3) sebagian besar siswa tidak mengalami kesulitan dalam mengikuti pembelajaran menulis puisi dengan penerapan metode Curah Pendapatoleh guru (4) sebagian besar siswa merespon positif terhadap pembelajaran dengan metode Curah Pendapat pada materi menulis puisi.
\end{abstract}

Kata Kunci:metode curah pendapat, menulis puisi

\begin{abstract}
This study aims to describe (1) the application of the Brainstorming method by Indonesian language teachers in learning to write poetry, (2) an obstacles faced by Indonesian teachers in applying the Brainstorming method to writing poetry learning, (3) an obstacles faced by students when Indonesian teachers apply Brainstorming method in poetry writing learning, (4) the student responses to learning to write poetry using the Bulk opinions method by Indonesian language teachers. The Subjects of the study is an Indonesian language teacher dan students of grade $X$ of sains class 2 in senior high school 1 Sawan. The object of research is the application of the Brainstorming method, an obstacle faced by teachers and students in applying the Brainstorming method, and responses from students to the application of the Brainstorming method to learning to write poetry. The data of the study collected through observation and interview methods. This study uses descriptive qualitative data analysis methods. The results of the study that (1) Brainstorming methods can be applied by the teacher well and according to procedures (2) there is no An obstacles faced by Indonesian teacher in applying the Brainstorming method to writing poetry learning (3) most students have no difficulty
\end{abstract}


learning to write poetry by applying the Brainstorming method by the teacher (4) most the students positive respond for learning with Brainstorming method in poetry writing learning.

Keywords : brainstorming method, write poetry

\section{PENDAHULUAN}

Pendidikan merupakan

suatu perantara setiap individu untuk memperoleh ilmu sehingga menjadi manusia yang berguna. Suprihatiningrum

(2016:7) mengatakan bahwa dalam iklim kehidupan berbangsa dan bernegara, sektor pendidikan memegang peranan penting dalam mengonstruksi pembangunan dan perkembangan. Menurut Wendra (2015:11) pendidikan adalah proses yang direncanakan agar semua potensi individu berkembang melalui proses pembelajaran. Berdasarkan beberapa pendapat tersebut, pendidikan merupakan suatu hal yang penting dalam kehidupan dan menjadi kebutuhan pokok bagi setiap individu.

Menurut Rahayu,dkk (2010:2) dalam dunia pendidikan, proses pembelajaran adalah proses yang melibatkan guru dan peserta didik. Dari pernyataan tersebut, tentu saja guru tidak dapat terlepas dalam kegiatan belajar dan pembelajaran. Guru memang sangat berperan penting dalam pembelajaran sebagai pengajar, motivator, fasilitator, sekaligus evaluator.

Menurut Wendra (2015:12) guru merupakan panutan yang perlu dicontoh sekaligus suri tauladan dalam kehidupan seharihari di mata masyarakat. Pelaksanaan tugas sebagai guru harus didukung oleh suatu perasaan bangga akan tugas yang dipercayakan kepadanya untuk mempersiapkan kualitas generasi masa depan bangsa. Guru harus mampu menciptakan suasana belajar yang interaktif, inspiratif, menyenangkan, menantang, dan memotivasi siswa berpartisipasi aktif. Berdasarkan hal tersebut, guru sebagai pengelola kelas memiliki peran yang sangat strategis dalam menentukan keberhasilan proses belajar mengajar.Dalam proses belajar mengajar, salah satu yang dapat melatih kemampuan berpikir siswa adalah kegiatan menulis puisi.

Puisi adalah salah satu karya sastra yang berasal dari ungkapan atau curahan perasaan dan pemikiran seorang penulis. Menurut Rahmanto (1988: 47) puisi merupakan bentuk karya sastra dengan bahasa yang terpilih dan tersusun dengan perhatian penuh dan keterampilan khusus. Bahasa terpilih yang dimaksud adalah bahasa yang padat dan penuh arti, serta bahasa kiasan yang dapat menimbulkan pengaruh keindahan khusus dalam menulispuisi.

Menulis puisi adalah salah satu keterampilan yang membutuhkan imajinasi tinggi supaya pembaca dapat masuk dalam suasana puisi dan menghayatinya. Imajinasi dari sang penulis puisi tidak dapat dibatasi dikarenakan penyair memiliki kebebasan untuk memperlakukan bahasa sebagai bahan puisi yang biasa disebut dengan Licentia Poetika. Menurut Ariadinata (2006:12) Licentia Poetika yakni kebebasan pengarang untuk merombak dan menyimpang dari kaidah bahasa yang telah ditentukan, bahkan bila dimungkinkan seorang 
pengaran bisa menciptkan/memunculkan katakata baru.

Pada dasarnya kegitan menulis merupakan keterampilan yang sulit bagi siswa, terlebih lagi menulis puisi.Tidak seperti kegiatan menulis lainnya, penulisan puisi harus memperhatikan makna dan keindahan kata atau kaidah bahasa, serta memperhatikan unsur dari puisi. Hal inilah yang membuat siswa kesulitan dalam menulis puisi. Jika ini terjadi dalam pembelajaran, maka dapat dikatakan bahwa guru belum mencapai keberhasilan mengajar. Dalam hal ini, guru dianjurkan untuk memperbarui cara mengajar, agar terdapat perubahan dalam pemahaman, motivasi, dan nilai siswa menjadi lebih baik lagi.

Penggunaan metode dalam perencanaan pembelajaran merupakan salah satu kunci agar pembelajaran dapat berjalan dengan lancar. Dari sekian banyak metode yang ada, tentu saja memiliki langkah-langkah yang berbeda di setiap penerapannya. Dalam hal ini, guru harus cerdas untuk memilih atau menggunakan metode yang dapat disesuaikan dengan materi yang akan diajarikannya. Metode pembelajaran yang tidak tepat dapat berpengaruh pada proses pembelajaran, sehingga berdampak kurang baik pada hasil belajar siswa.

Salah satu guru bahasa Indonesia yang mengajar di kelas $X$ IPA 2 di SMA Negeri 1 Sawan berhasil memilih dan menerapkan metode yang sesuai dalam pembelajaran menulis puisi yaitu metode Curah Pendapat, sehingga banyak siswa yang mendapatkan nilai di atas KKM yaitu (75).

Metode Curah Pendapat (Brainstorming) adalah teknik penyelesaian masalah yang dapat digunakan baik secara individual maupun kelompok. Hal ini mencakup pencatatan gagasan-gagasan yang terjadi spontan tanpa menghakimi atau menerima semua komentar atas masalah yang diberikan tanpa perlu dikomentari lagi.

Selain menyesuaikan metode pembelajaran dengan materi yang akan diajarkan, guru juga harus melihat kelebihan dari metode yang digunakan supaya kecil kemungkinan terjadinya kendala dalam pembelajaran.

Seperti yang diungkapkan oleh Hamdani (2011: 266) bahwa kelebihan metode Brainstorming yaitu (1) suasana disiplin dan demokratis dapat tumbuh; (2) siswa aktif untuk menyatakan pendapatnya; (3) melatih siswa untuk berpikir dengan cepat dan tersusun logis; (4) merangsang siswa untuk selalu berpendapat yang berhubungan dengan masalah yang diberikan oleh guru; (5) terjadi persaingan yang sehat; (6) meningkatkan partisipasi siswa dalam menerima pelajaran; (7) anak merasa bebas dan gembira; (8) siswa yang kurang aktif mendapat bantuan dari temannya yang pandai atau dari guru; (9) ide yang muncul lebih banyak dan beragam karena siswa dengan bebas menyalurkan ide tersebut tanpa adanya kritik; (10) siswa berpikir untuk menyatakan pendapat karena kreatifitas tidak terbatas; (11) dapat meningkatkan kemampuan berpikir kreatif anak.

Dalam penelitian ini, peneliti perlu mengetahui informasi 
mengenai cara penerapan dari metode Curah Pendapat pada pembelajaran menulis puisi di kelas X IPA 2. Hal ini merupakan informasi penting bagi peneliti.

Selain itu, peneliti juga perlu mengetahui informasi mengenai kendala yang dihadapi dalam menerapkan metode Curah Pendapat pada pembelajaran menulis puisi, baik kendala yang dialami oleh guru dan siswa. Sehingga peneliti dapat mengetahui kondisi dalam proses pembelajaran dan mengantisipasi kendala yang ada bagi penggunaan metode ini untuk hasil yang lebih baik.

Adapun informasi lain yang perlu diketahui oleh peneliti yaitu respons siswa terhadap penerapan metode Curah Pendapat. Hal ini dikarenakan respons yang diberikan oleh siswa menunjukkan keberhasilan guru dalam menerapkan metode Curah Pendapat pada pembelajaran menulis puisi.

Dari latar belakang di atas, maka masalah yang akan dibahas dalam penelitian ini yaitu (1) penerapan metode Curah Pendapat oleh guru bahasa Indonesia pada pembelajaran menulis puisi; (2) kendala yang dihadapi guru bahasa Indonesia dalam menerapkan metode Curah Pendapat pada pembelajaran menulis puisi; (3) kesulitan yang dihadapi siswa ketika guru bahasa Indonesia menerapkan metode Curah Pendapat dalam pembelajaran menulis puis; (4) respons siswa terhadap pembelajaran menulis puisi menggunakan metode Curah Pendapat.

Tujuan penelitian ini adalah mendeskripsikan penerapan metode Curah Pendapat oleh guru bahasa Indonesia pada pembelajaran menulis puisi, mendeskripsikan kendala yang dihadapi guru bahasa Indonesia dalam menerapkan metode Curah Pendapat pada pembelajaran menulis puisi di kelas, mendeskripsikan kendala yang dihadapi siswa ketika guru bahasa Indonesia menerapkan metode Curah Pendapat dalam pembelajaran menulis puis di kelas, dan mendeskripsikan responss siswa terhadap pembelajaran menulis puisi menggunakan metode Curah Pendapat oleh guru bahasa Indonesia di kelas X IPA 2 SMA Negeri 1 Sawan.

Hasil penelitian ini diharapkan dapat memberikan manfaat bagi beberapa pihak, baik secara teoretis maupun praktis. Secara teoretis, hasil penelitian ini diharapkan dapat memberikan sumbangan pemikiran atau teori dalam pembelajaran menulis puisi dengan menggunakan metode Curah Pendapat pada mata pelajaran bahasa Indonesia. Secara praktis, penelitian ini akan memberikan manfaat bagi pihak, yaitu (1) bagi guru, hasil penelitian ini dapat digunakan sebagai bahan evaluasi terhadap pembelajaran menulis puisi yang telah berlangsung, sehingga dapat mengantisipasi terjadinya kendala-kendala yang dihadapi; (2) bagi siswa, pembelajaran menggunakan metode Curah Pendapat ini akan mendorong para siswa untuk lebih aktif, kreatif, inovatif serta mengembangkan keterampilan menulis puisi pada siswa; (3) bagi sekolah, hasil penelitian ini dapat memberikan sumbangan yang positif terhadap kemajuan 
sekolah, yang tercermin dari peningkatan kemampuan profesional guru, perbaikan proses, dan kebermaknaan hasil belajar siswa dalam pembelajaran menulis puisi; (4) bagi peneliti lain, hasil penelitian ini bisa digunakan sebagai bahan informasi dan referensi bagi peneliti lain yang memerlukan hasil dari penelitian ini sebagai bahan perbandingan untuk melakukan penelitian sejenis.

\section{METODE PENELITIAN}

Metode
membantu menuntun penelitian
dalam melakukan kegiatan
penelitian. Tercapai tidaknya
tujuan penelitian, sangat
bergantung pada metode yang
digunakan. Metode penelitian
hendaknya harus sejalan dengan
rumusan masalah dan tujuan
yang akan dicapai. Adapun
bagian-bagian dari metode
penelitian ini yaitu sebagai
berikut.

Rancangan penelitian yang digunakan dalam penelitian ini adalah deskriptif kualitatif, agar tujuan penelitian dapat tercapai. Menurut Setyosari (2013:201) rancangan penelitian dibuat untuk menjadikan peneliti mampu menjawab pertanyaan (masalah) penelitian dengan valid, objektif, tepat, efesien. Rancangan penelitian disusun dengan penuh perhitungan agar dapat menghasilkan petunjuk empiris yang kuat relevansinya dengan masalah penelitian yang ada.

Rancangan penelitian deskriptif kualitatif digunakan untuk memperoleh gambaran yang jelas, objektif, sistematis, dan cermat mengenai fakta-fakta aktual dari sifat populasi (Margono, 2003:36).

Sumber data sangat penting dalam penelitian. Penelitian tidak akan berjalan jika tidak adanya subjek dan objek yang akan diteliti. Hal tersebut sejalan dengan pendapat Suandi (2008:31)bahwa subjek penelitian adalah benda, hal, atau orang, tempat variabel melekat, dan yang dipermasalahkan dalam penelitian. Subjek dalam penelitian ini adalah guru bahasa Indonesia kelas $X$ dan siswa kelas X IPA 2.

Objek penelitian juga diperlukan dalam penelitian untukdikaji. Sejalan dengan hal tersebut, Sugiono (2007: 298) menyatakan bahwa objek penelitian merupakan hal yang ingin dipahami secara lebih mendalam yang terjadi di dalamnya. Objek dalam penelitian ini adalah penerapan metode Curah Pendapat (Brainstorming) oleh guru, kendala-kendala yang dihadapi oleh guru dan siswadalam penerapan metode Curah Pendapat,serta respons dari siswa terhadap penerapan metode Curah Pendapat pada pembelajaran menulis puisi.

Lokasi penelitian yang dilakukan oleh peneliti bertempat di kelas X IPA 2 SMA Negeri 1 Sawan yang terletak di Banjar Abasan, Desa Sangsit, Kecamatan Sawan, Buleleng.

Metode pengumpulan data yang digunakandalam penelitian ini adalah metode observasi dan metode wawancara.Instrument penelitian yang digunakan dalam penelitian ini yaitu lembar observasi,alat perekam, dan pedoman wawancara.

Metode analisis data yang digunakan dalam penelitian ini 
yaitu metode analisis deskriptif kualitatif.

\section{HASIL PENELITIAN DAN PEMBAHASAN}

Hasil penelitian ini mencangkup (1) penerapan metode Curah Pendapat oleh guru bahasa Indonesia pada pembelajaran menulis puisi di kelas X IPA 2, (2) kendala yang dihadapi guru bahasa Indonesia dalam menerapkan metode Curah Pendapat pada pembelajaran menulis puisi di kelas X IPA 2, (3) kesulitan yang dihadapi siswa ketika guru bahasa Indonesia menerapkan metode Curah Pendapat dalam pembelajaran menulis puis di kelas X IPA 2, dan (4) respons siswa terhadap pembelajaran menulis puisi menggunakan metode Curah Pendapat oleh guru bahasa Indonesia di kelas $X$ IPA 2.Data penelitian ini diperoleh dari hasil observasi, dan wawancara dengan siswa dan guru.

Dalam menerapkan metode Curah Pendapat, guru mengawali pembelajaran mengontrol kerajinan dan kedisiplinan siswa. Kemudian guru menyampaikan KD dan indikator sesuai dengan materi yang akan diajarkan. Guru tidak lupa menyampaikan tujuan dari kebermaknaan pembelajaran menulis puisi serta menyampaikan langkah-langkah pembelajaran berdasarkan metode Curah Pendapat dan teknik penilaian (lisan/tertulis) kepada peserta didik. Sebelum masuk pada materi, guru menghantarkan pembelajaran dengan apersepsi.

Guru membagi siswa ke dalam beberapa kelompok (heterogen) yang diperoleh dengan cara berhitung. Bagi siswa yang mendapatkan angka yang sama, maka siswa tersebut akan menjadi satu kelompk. Dari 33 orang siswa yang ada di kelas $X$ IPA 2, guru membentuk 6 kelompok yang terdiri atas tiga kelompok beranggotakan 6 orang siswa dan tiga kelompok beranggotakan 5 orang siswa. Masing-masing siswa duduk sesuai dengan kelompok yang telah dibagikan oleh guru. Sebelum siswa duduk bersama teman kelompoknya dan mengerjakan tugas kelompok, guru melanjutkan pembahasan materi pembelajaran berkaitan dengan menulis puisi. Dalam proses pengerjaan tugas yaitu menulis puisi, guru membebaskan tema puisi yang diangkat sebagai puisi dari masing-masing kelompok. Setalah itu guru meminta setiap perwakilan kelompok untuk membacakan puisi kelompoknya masing-masing di depan kelas. Setiap kelompok menyiapkan pendapat dari puisi yang dibacakan oleh ketua kelompok lain. Kelompok yang diberikan pendapat tidak diperbolehkan mencela, mengkritik, atau menghentikan pendapat yang sedang dibacakan oleh para ketua kelompok lainnya. Hal tersebut merupakan salah satu langkah terpenting dari metode Curah Pendapat yaitu semua pendapat ataupun pendapat yang masuk ditampung, ditulis, dan tidak dikritik.

Ketika seluruh kelompok telah selesai menampilkan puisinya, maka tahap selanjutnya yang harus dilewati dalam menggunakan metode Curah Pendapat adalah verifikasi yaitu 
guru bersama seluruh kelompok membahas pendapat yang telah dibuat. Sebelumnya guru meminta ketua kelompok menggabungkan semua pendapat dari kelompoknya untuk dibacakan pada kelompok yang dituju.

Langkah terakhir dalam
menggunakan pembelajaran curah pendapat adalah konklusi. Konklusi yang dimaksud yaitu guru menyimpulkan sumbang pendapat yang telah diverifikasi. Jadi, setelah ketua kelompok membacakan butiran-butiran pendapat untuk puisi kelompok lain kepada guru, maka guru menyimpulkan pendapat mana saja yang dapat diterima atau tidak. Adapun pendapat yang tidak terpilih dikarenakan beberapa faktor yaitu memiliki kesamaan dengan pendapat kelompok sebelumnya dan pendapat yang hanya sekadar pendapat yang tidak dapat dijelaskan oleh siswa yang memberi pendapat. Dalam hal ini, perlunya guru memilah pendapat yang disampaikan pada langkah konklusi, supaya pendapat yang dibacakan jelas dan bersifat membangun rasa percaya diri siswa sehingga menjadi lebih termotivasi dalam pembelajaran menulis puisi.

Setelah kegitan inti dalam pembelajaran selesai, guru menutup pembelajaran dengan menyampaikan kepada semua kelompok mengenai perbaikan puisi melalui pendapat dari semua siswa. Kemudian guru mengadakan refleksi ke semua kelompok mengenai perbaikan puisi yang dilanjutkan dengan mengadakan evaluasi pada semua kelompok terhadap puisi yang telah diperbaiki.

Berdasarkan metode observasi dan wawancara yang dilakukan, diperoleh hasilsebagai masalah penelitiannya.

Hasil pertama, guru berhasil menerapkan metode curah pendapat sesuai dengan RPP yang telah dibuat. Selain itu, metode yang digunakan berdasarkan wawancara yang dilakukan cocok untuk materi menulis puisi. Penerapan metode Curah Pendapat oleh guru terhadap siswa dibimbing secara bertahap sehingga siswa juga dapat mengikuti pembelajaran dengan baik. Hal Ini dapat dibuktikan dengan kondisi dalam pembelajaran terlihat kondusif dan peserta didik tampak senang dalam menerima pelajaran, serta siswa terlihat mudah memahami yang telah dijelaskan oleh guru.

Keberhasilan guru dalam menerapkan metode Curah Pendapat ini sejalan dengan penelitian Sri Wahyuni (2017) yang berjudul "Penerapan Model Pembelajaran Curah Pendapat untuk Meningkatkan Motivasi Belajar Siswa di Kelas VII A SMP Negeri 6 Cilacap". Dalam penelitian Sri Wahyuni memaparkan bahwa adanya keberhasilan pada peningkatan motivasi siswa dalam menerapkan metode Brainstorming atau Curah Pendapat. Keberhasilan dalam menerapkan metode Brainstorming membuat motivasi siswa menjadi lebih baik lagi dalam mengikuti pembelajaran. $\mathrm{Hal}$ ini menujukkan bahwa metode tersebut baik digunakan sehingga mampu mencapai tujuan yang ingin dicapai seperti meningkatkan motivasi siswa. 
Hasil kedua, guru tidak mengalami kendala saat menerapkan metode Curah Pendapat dalam pembelajaran menulis puisi di kelas X IPA 2. Dalam kegiatan pembelajaran, guru selalu berupaya untuk mengoptimalkan pencapaian tujuan pembelajaran dan meningkatkan minat belajar siswa.Keberhasilan tersebut juga dipengaruhi oleh cara guru dalam menggunakan strategi pembelajaran di kelas sehingga menimbulkan kondisi yang kondusif. Dalam hal ini, guru telah mengoptimalkan kemampuannya sehingga guru tidak memiliki kendala baik dari segi penguasaan materi, pemahaman prosedur metode Curah Pendapat, sarana, media pembelajaran, dan pelaksanaan pembelajaran dengan metode Curah Pendapat.

Hasil penelitian ini sejalan dengan penelitian yang dilakukan oleh Ramadhoni (2014) dengan judul "Efektifitas Penerapan Metode Brainstorming Terhadap Peningkatan Minat dan Prestasi Belajar", bahwa penerapan metode Brainstorming telah terlaksana dengan baik, sesuai dengan prosedur yang ada. Oleh sebab itu, di dalam penelitian ini Ramadhoni sebagai pengamat memaparkan bahwa guru tidak memiliki kendala dalam penerapan metode Brainstorming, baik dari segi perencanaan maupun pelaksanaan. Hal ini juga didukung dari motivasi siswa dalam mengikuti pelaksanaan pembelajaran dengan metode Brainstorming yang berjalan dengan baik.

$$
\text { Hasil ketiga, sebagian }
$$

besar siswa tidak memiliki kesulitan dalam pembelajaran menulis puisi dengan penerapan metode Curah Pendapat, bahkan banyak siswa yang merasa terbantu dengan diterapkannya metode Curah Pendapat.Di sisi lain, hanya sebagian kecil siswa yang mengalami kesulitan. Secara umum kesulitan yang dialami siswa adalah kegiatan bekerja kelompok. Siswa menganggap bahwa dengan menulis puisi secara berkelompok dapat membingungkan dalam menampung semua ide-ide yang bermunculan.Berdasarkan jawaban tersebut, siswa masih belum mampu berdiskusi dengan baik dikarenakan pada metode Curah Pendapat menekankan pada kemampuan siswa untuk berani memberikan pendapat agar dapat lebih aktif dan lebih berani di dalam kelas. Hal ini tentu saja berkaitan dengan pribadi setiap siswa yang berbeda-beda dari segi pemahaman, keseriusdalam mengikuti pembelajaran, dan lain sebagainya.

Hasil penelitian ini sejalan dengan penelitian yang dilakukan oleh Marlina Yuliantika Dewi (2014) yang berjudul "Penerapan Metode Pembelajaran Brainstorming Melalui Media Gambar untuk Meningkatkan Kemampuan Menulis Karangan Narasi Ekspositoris pada Siswa Kelas IV A SDN 68 Kota Bengkulu". Dalam penelitian Marlina, terdapat pembahasan terkait kendala siswa. Adapun beberapa kendala siswa yang disampaikan dalam penelitan Marlina terjadi karena faktor siswa itu sendiri, seperti siswa kurang membaca sebagai dasar untuk memahami referensi acuan yang ada, siswa kurang 
berpartisipasi aktif, dan siswa kesulitan memberikan pendapat karena pendapat yang ada ratarata telah disampaikan oleh siswa lainnya.

Dari beberapa kendala tersebut, dapat dipastikan bukan berasal dari cara penerapan metode Brainstorming di dalam kelas, karena sebagian besar siswa tidak mempunyai kendala, serta pada penerapan metode maupun kemampuan menjelaskan materi tidak adanya hambatan dan terlaksana dengan baik. Ditambah dengan penggunaan media gambar yang mampu mempermudah pemahaman siswa dan pembelajaran terasa lebih menarik, sehingga penelitian Marlina telah berhasil.

Hasil keempat, sebagian besar siswa memberikan respons positif terhadap penggunaan metode Curah Pendapat oleh guru, sehingga banyak siswa yang ingin metode Curah Pendapat untuk diteruskan dalam pembelajaran menulis puisi. Hal ini telah ditegaskan oleh Fasko (2001) bahwa metode Curah Pendapat merupakan salah satu metode yang dapat meningkatkan kreativitas siswa dari segi pemahaman terhadap kemampuannya, sehingga siswa merasa tertarik dan dipermudah dari cara mengajar guru. Oleh sebab itu, pembelajaran dengan menggunakan metode Curah Pendapat dapat membuat siswa memberikan respons yang bagus dan layak direkomendasikan untuk pembelajaran menulis puisi.

Hasil penelitian ini sejalan dengan penelitian yang dilakukan oleh Tarmiji,dkk (2016) yang berjudul "Persepsi Siswa
Terhadap Kesiapan Guru dalam Proses Pembelajaran dengan Metode Curah Pendapat". Dalam penelitian Tarmiji, dkk memaparkan tentang persepsi siswa terhadap kesiapan guru dalam proses belajar mengajar yang memiliki hasil positif dengan kategori baik terhadap pembelajaran.Hal tersebut disebabkan oleh keunggulan dari metode Curah Pendapat yang dilakukan secara berkelompok, sehingga sebagian besar siswa dapat mengikuti metode dan memahami materi dengan baik. Selain itu, penerapan yang terbimbing dengan baik oleh guru juga mendukung proses pembelajaran, sehingga siswa memberikan hasil respons yang positif.

Penelitian ini kajiannya terbatas pada penggunaan metode Curah Pendapat pada pembelajaran menulis puisi. Padahal metode ini juga bisa diterapkan pada materi pembelajaran lain seperti menulis cerita pendek, naskah drama, dan sebagainya. Hal ini dapat menjadi peluang bagi peneliti lain untuk meneliti dari aspek yang belum diteliti, misalnya penggunaan metode Curah Pendapat dalam pembelajaran menulis cerita pendek, menulis naskah drama, dan lain sebagainya.

\section{SIMPULAN DAN SARAN}

Simpulan dalam penelitian ini, yaitu pada penerapan metode Curah Pendapat, kegiatan pertama diawal dengan memberikan salam yang dilanjutkan dengan berdoa, dan mengecek kehadiran siswa. Lalu guru memberikan apersepsi kepada siswa sebelum memasuki 
kegiatan inti. Setelah itu, guru membentuk siswa menjadi beberapa kelompok untuk mengerjakan tugas menulis puisi bebas.

Kemudian masuk ke dalam kegiatan inti dengan menerapkan prosedur metode Curah Pendapat yaitu (1) Pemberian informasi dan motivasi seperti memberikan contoh puisi dan menjelaskannya kepada siswa, supaya siswa dapat menulis puisi setelahnya; (2) Identifikasi seperti siswa diminta memilih ketua kelompok untuk membacakan puisi yag telah dibuat bersama, kemudian setiap individu harus mampu memberikan pendapatnya pada puisi kelompok lain tanpa boleh menyanggah; (3) Klarifikasi seperti menggabungkan pendapat dan saran masingmasing kelompok; (4) Verifikasi seperti pengumpulan berbagai pendapat; dan (5) Konklusi seperti evaluasi dari guru terhadap seluruh kelompok mengenai pendapat dan saran yang tepat.

Pada kegiatan penutup, guru melakukan refleksi dan menyampaikan informasi mengenai rencana tindak lanjut pembelajaran pada pertemuan selanjutnya.

Guru tidak mengalami kendala dalam pelaksanaan penerapkan metode Curah Pendapat pada pembelajaranmenulis puisi di kelas X IPA 2. Dalam kegiatan pembelajaran, guru selalu berupaya untuk mengoptimalkan pencapaian tujuan pembelajaran dan meningkatkan minat belajar siswa.

Dalam hal ini guru tidak memiliki kendala baik dari segi penguasaan materi, pemahaman prosedur metode Curah Pendapat, sarana, media pembelajaran, dan pelaksanaan pembelajaran dengan metode Curah Pendapat.

Pada pembelajaran menulis puisi dengan metode Curah Pendapat, sebagian besar siswa tidak mengalami kesulitan, bahkan banyak siswa yang merasa terbantu dengan diterapkannya metode Curah Pendapat.Di sisi lain, hanya sebagian kecil siswa yang mengalami kesulitan. Secara umum kesulitan yang dialami siswa adalah kegiatan bekerja kelompok. Siswa menganggap bahwa dengan menulis puisi secara berkelompok dapat membingungkan dalam menampung semua ide-ide yang bermunculan.

oleh $\begin{array}{cc}\text { Respons yang diberikan } \\ \text { siswa }\end{array}$ pembelajaran menulis puisi dengan menggunakan metode Curah Pendapat sebagian besar positif, sehingga banyak siswa yang ingin metode Curah Pendapat bisa diteruskan oleh guru dalam pembelajaran menulis puisi.

Saran yang dapat disampaikan dalam penelitian ini, yaitu disarankan kepada guru agar tetap menerapkan metode ini bahkan meningkatkan kualitas dalam penerapan metode Curah Pendapat.

Guru bahasa Indonesia lainnya disarankan untuk mencoba menerapkan metode Curah Pendapat dalam kegiatan pembelajaran di kelas, karena penggunaan metode Curah Pendapat bermanfaat untuk melatih keterampilan berpikir tingkat tinggi siswa. Selain itu, 
disarankan kepada guru agar lebih mengikuti perkembangan dunia pendidikan khususnya pada media pembelajaran, agar memahami cara penggunaan media yang lebih canggih seperti LCD, sehingga siswa dapat lebih bersemangat dalam mengikuti pembelajaran.

Bagi siswa disarankan untuk lebih berani bertanya jika kurang memahami penjelasan dari guru, selain itu siswa diharapkan lebih bisa bekerja secara berkelompok karena melatih kerjasama dan mampu menerima pendapat atau ide dari orang lain dapat menambah wawasan siswa.

Dalam memberikan pendapat juga diharapkan siswa tidak ragu karena menyampaikan suatu pemikiran atau pendapat terhadap orang lain akan mendambahkan rasa percaya diri siswa, rasa ingin tahu siswa, dan berpikir kritis siswa, sehingga siswa dapat lebih serius dalam menyimak pembelajaran.

\section{DAFTAR RUJUKAN}

Ariadinata,Joni. 2006. Aku Bisa Nulis Cerpen. Jakarta: Gema Insani Press

Fasko, D. 2001. Education and Creativity. Creativity Research Journal 20002001, Vol. 13, Nos. 3\&4,
317-327. Bowling Green State University. Lawrence Erlbaum Associates, Inc.

Hamdani . 2011. Strategi Belajar Mengajar. Bandung :

Pustaka Setia

Margono, S. 2003. Metodologi

Penelitian. Jakarta: PT.

Rineka Cipta

Munandar, Utami. 1985. Mengembangkan Bakat dan Kreatifitas Anak Sekolah. Jakarta : PT Gramedia

Rahayu, Endang Sadbudhy, dkk. 2010. Pembelajaran Masa Kini. Jakarta : Sekarmita Training and Publishing

Setyosari, Punaji. 2016. Metode Penelitian Pendidikan dan Pengembangan. Jakarta : Prenadamedia Group

Suandi, I Nengah. 2008. Metode Penelitian Bahasa. Singaraja : Undiksha

Sugiyono. 2007. Metode Penelitian Kuantitatif Kualitatif dan $R \& D$. Bandung : Alfabeta

Rahmanto, B. 1988. Metode Pengajaran Sastra. Yogyakarta : Kanisius

Suprihatiningrum, Jamil. 2016. Guru Profesional. Jogjakarta : AR-RUZZ MEDIA

Wendra, I Wayan. 2015. Profesi Kependidikan. Singaraja : Universitas Pendidikan Ganesha 